\title{
QUANTITATIVE VISUALISATION OF COMPRESSIBLE FLOWS
}

\author{
Wit Stryczniewicz \\ Aerodynamics Department, Institute of Aviation \\ al. Krakowska 110/114, 02-256 Warsaw, Poland \\ wit.stryczniewicz@ilot.edu.pl
}

\begin{abstract}
The paper demonstrates the feasibility of quantitative flow visualisation methods for investigation of transonic and supersonic flows. Two methods and their application for retrieving compressible flow field properties has been described: Background Oriented Schlieren (BOS) and Particle Image Velocimetry (PIV). Recently introduced BOS technique extends the capabilities of classical Schlieren technique by use of digital image processing and allow to measure density gradients field. In the presented paper a review of applications of BOS technique has been presented. The PIV is well established technique for whole field velocity measurements. This paper presents application of PIV for determination of the shock wave position above airfoil in transonic flow regime. The study showed that application of quantitative flow visualisation techniques allows to gain new insights on the complex phenomenon of supersonic and transonic flow over airfoils like shock-boundary layer interaction and shock induced flow separation.
\end{abstract}

Keywords: compressible fluid flow, flow visualisation, wind tunnel studies, Particle Image Velocimetry, Background Oriented Schlieren.

\section{INTRODUCTION}

Progress in optimization of the aerodynamic performance of new aircrafts [1-3] require detailed information of the flow field. Particularly, 2D and 3D flow field properties in form of scalar and vector maps are used for evaluation of Computational Fluid Dynamics (CFD) codes and performance of new aerodynamic solutions like novel flow control devices and noise reduction. Quantitative flow visualisation can be of major importance in case where the results of CFD simulations needs to be carefully validated i.e. in high angle of attack aerodynamics or in case when the flow is affected by the presences of nonlinearities and instabilities. Moreover, optical measurements are non-intrusive and do not require to use a measurement probe which interfere with delicate flow structures. Therefore, one can observe extensive development and application of new flow visualisation techniques in all aspects fluid mechanics measurements. For example in recent two projects Advanced In-flight Measurement Techniques (AIM) 
and Advanced In-flight Measurement Techniques $2\left(\mathrm{AIM}^{2}\right)$ conducted inter alia by leading German and French aerospace centres DLR and ONERA respectively. Both stages of the AIM project were carried out in the 7th Framework Programme funded European Research and Technological Development.

Application of quantitative flow visualisation can be particularly advantageous in transonic flow regime, where the shock boundary layer interaction influences the flow filed [4]. This might cause dangerous unsteady buffet loads acting on airplanes and rockets structure. The applied research on development of new quantitative flow visualisation techniques for investigations in transonic and supersonic flow are therefore important for control, economics and safety reasons.

Digital image processing allows to retrieve quantitative information from experimental flow images. Particularly, analysing of images of discrete particles suspended in the flow proved to be very effective approach for whole field velocimetry. Digital analysis based on tracing of individual particles and statistical correlation of particle patterns [5] has been used for determination of vector velocity field of investigated flows. The second approach proved to be more robust due to elimination of error-prone procedure of individual particle pairs identification. Advances in fast computer biased statistical interrogation procedures, digital charge coupled device (CCD) cameras and illumination technology resulted in development of Digital Particle Image Velocimetry DPIV [6]. The PIV method is currently used for velocity measurements of fluid flow in wind and hydrodynamic tunnels. Most often, two dimensional (two components of velocity in two dimensional plane - 2D2C) and stereo-PIV (three components of velocity in two dimensional plane - 2D3C [7]) measurements are performed. Recent developments in application of image reconstruction techniques allow to investigate highly three dimensional flows with use of volumetric and tomo-PIV (3D3C - three components of velocity in three dimensional volume [8]). Advance of high repetition lasers and fast cameras allowed for time resolved (TR) whole field measurements. TR-PIV provide data suitable for investigations of turbulence and turbulent flows as well as retrieving pressure field form material acceleration data.

Recently, the digital image processing of discrete patterns was used for development of new technique for quantitative measurements of compressible flows. Background-oriented schlieren (BOS) method is based on imaging of distortion of background caused by changes of the refraction index of medium in region between a camera and the background. The changes of the refraction index are proportional to the density change and therefore determination of apparent movement of background pattern can be used for quantitative determination of the density gradients in the investigated flow. Application of BOS technique may provide new quantitative data in investigations of flow transonic flow regime.

In the presented paper two methods suitable for quantitative flow visualisation of compressible flows regime are described. First part describes principles of Background Oriented Schlieren an provide examples of applications. In second part an experimental investigation of flow field above airfoil by means of Particle Image Velocimetry is presented.

\section{BACKGROUND ORIENTED SCHLIEREN}

Investigation of density gradients has made great contribution in understanding of compressible flow phenomena. For example, the Schlieren photography was used for investigation of transonic flow over airfoils. Early works in that field was one of major importance for advance of manned supersonic flight. The classical Schlieren technique has significantly contributed to understanding of transonic and supersonic flow over various bodies like airplanes, aerofoils and reentry vehicles. The schlieren flow visualisation is based on the deflection of a light beam caused by spatial gradients of refractive index 
proportional to the density gradients in the flow. The classical Toepler schlieren and shadowgraph technique require parallel light beam. Therefore, careful alignment of schlieren optical setup is required (light source, spherical mirrors or lenses and half aperture).

The background oriented schlieren is based on the analysis of image displacements. In principle the background pattern is illuminated by incoherent light and imaged through a fluid containing spatial density gradients (See figure 1). Since coherent beam of light is not required, the BOS setup is much simpler than classical schlieren apparatus.

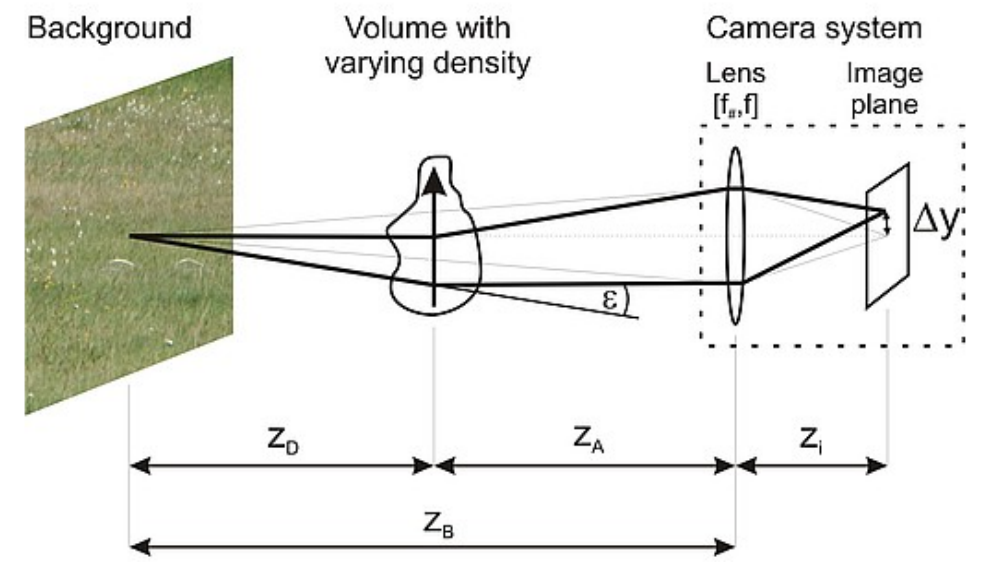

Fig. 1. Sketch of a typical Background-oriented schlieren setup [http://aim2.dlr.de/measurement-techniques/ background-oriented-schlieren-method-bos/index.html]

BOS measurement procedure include following steps: i) a reference image of background in acquired, ii) the background is viewed through the medium with density medium and the image is acquired during the wind tunnel run, iii) the density gradient field is determined. Typically cross-correlation analysis adopted from PIV technique is used [8]. Resulting vector field represents gradients of the density field [9]. Exemplary displacement vector field is presented in figure 2, the arrows are pointing towards lower density.

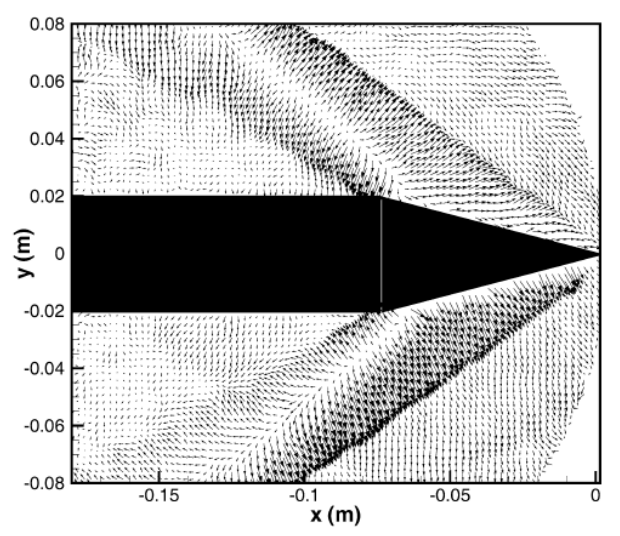

Fig. 2. Supersonic flow over cone. The average displacement field: vectors of density gradients [9] 
BOS technique allows to quantitative measure the density filed by solving the Poisson equation (1) from the density gradients calculated at each mesh point and appropriate boundary conditions.

$$
\frac{\partial^{2}}{\partial x^{2}} \rho(x, y)+\frac{\partial^{2}}{\partial y^{2}} \rho(x, y)=\nabla^{2} \rho
$$

\subsection{Exemplary applications of BOS}

Recently the BOS has gained much attention of the fluid mechanic research community for few reasons. Firstly, the simplicity of the setup makes the technique favourable for applications in wind tunnels with restricted space. Comparison between performance of the classical system and BOS is presented in figure 3 and can be found in [10]. Secondly, quantitative flow visualisation is possible by the determination of the density field form BOS measurement data. For example, by solving the Poisson equation (see [8]). Finally, BOS technique can be used with natural background pattern (desert sand, grass, leafs, etc.) so the full scale flows over aircrafts [12] (see figure 4 left) and helicopters [13] (figure 4 right) in real operating conditions can be instigated.
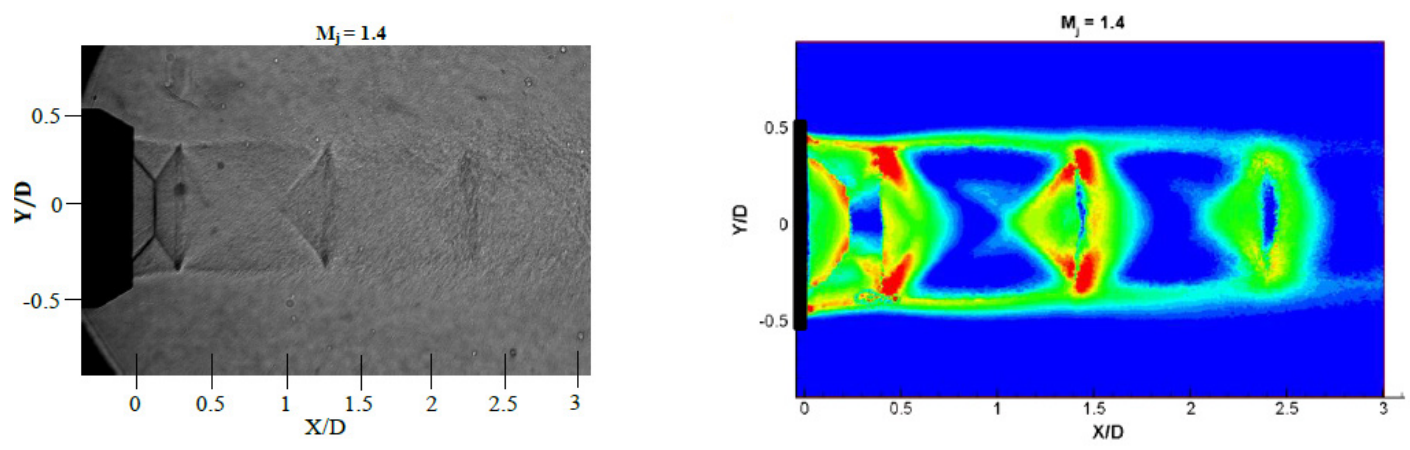

Fig. 3. Left: Shadowgraph images of nozzle flow for $M=1.4$, right: $B O S$ images for $M=1.4$, colours represents the magnitude of the density gradients [11]

\section{PIV MEASUREMENTS OF TRANSONIC FLOW FIELD}

The Particle Images Velocimetry (PIV) is instantaneous whole field velocity measurements technique [12] applied in fluid dynamic research, aerodynamics [15] and related fields [16]. Examples of application of PIV method for investigation of compressible flows can find in $[17,18]$. The shock wave boundary layer interaction (SWBLI) was investigated with PIV method by Giepman [19]. Hartmann [20] performed time resolved stereo PIV measurements of unsteady shock-boundary layer interaction on a supercritical airfoil.

In the following part of the article an application of PIV method for investigations of shock oscillations above the surface of an airfoil is presented. The experiments was performed in high speed wind tunnel N-3 in the Institute of Aviation, Warsaw, Poland [21]. In a course of the presented study a 2D vector velocity field of the flow over an airfoil for Mach number of 0.7 and 0.75 has been determined. The PIV measurements results were used for determination of the shock wave position in relation to the chord of the airfoil. The results were presented at "30th Congress of the International Council of Aeronautical Sciences ICAS2016” in Deajeon, Korea (25-30.09.2016), paper Id 300. 

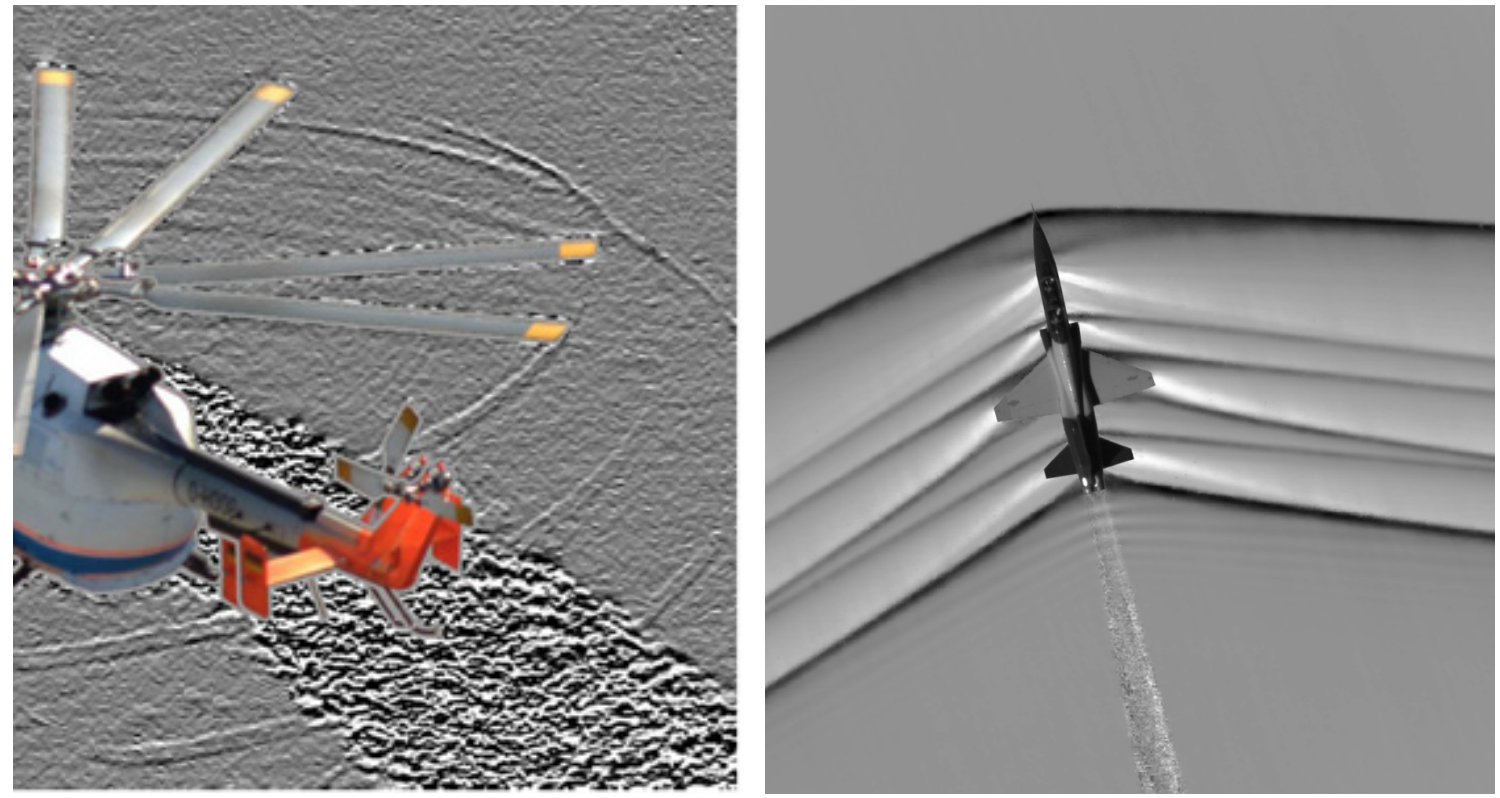

Fig. 4. Left: BOS visualisation of blade tip and engine exhaust gases [12], right: AirBOS technique displays the shock wave of a supersonic jet flying over desert [Credits: NASA Photo]

\subsection{Exemplary application of PIV for investigations at transonic speeds}

The N-3 wind tunnel is a closed circuit blow down type wind tunnel with a partial recirculation of the flow. The cross-section of the test chamber is a square of side $\mathrm{H}=0.6 \mathrm{~m}$. The flow field above V2C airfoil was investigated for Mach number 0.7 with accuracy \pm 0.01 . The airfoil has been under investigation in the TFAST project (TFAST - Transition Location Effect on Shock Wave Boundary Layer Interaction program, Seventh Framework Programme European Union). The airfoil chord was c $=0.2$ m. Measurements of the flow field were performed by PIV method at airfoil's incidence angle $0,1^{\circ}, 2^{\circ}$, $\ldots, 7^{\circ}$ for 2 seconds. Detailed description of the PIV system can be found in [22]. the field of view of the PIV camera is presented in figure 5.

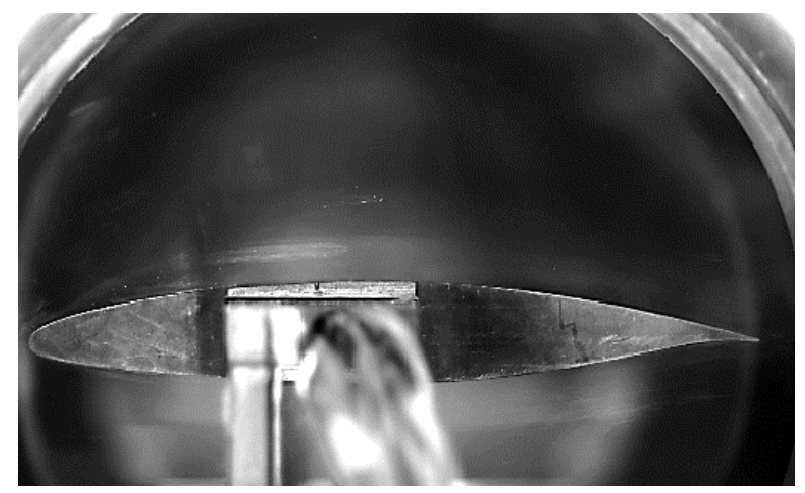

Fig. 5. View of the investigated airfoil in the test section of the IoA N-3.

PIV camera field of view [Stryczniewicz, 2014] 
An exemplary result of the PIV measurement in form of instantaneous vector velocity field is presented in figure 6. An abrupt decrease of the flow velocity at the shock terminating the supersonic flow region above the airfoil surface can be observed. The flow separation starts close to shock wave at approximate position $\mathrm{x} / \mathrm{c} \approx 0.7$.

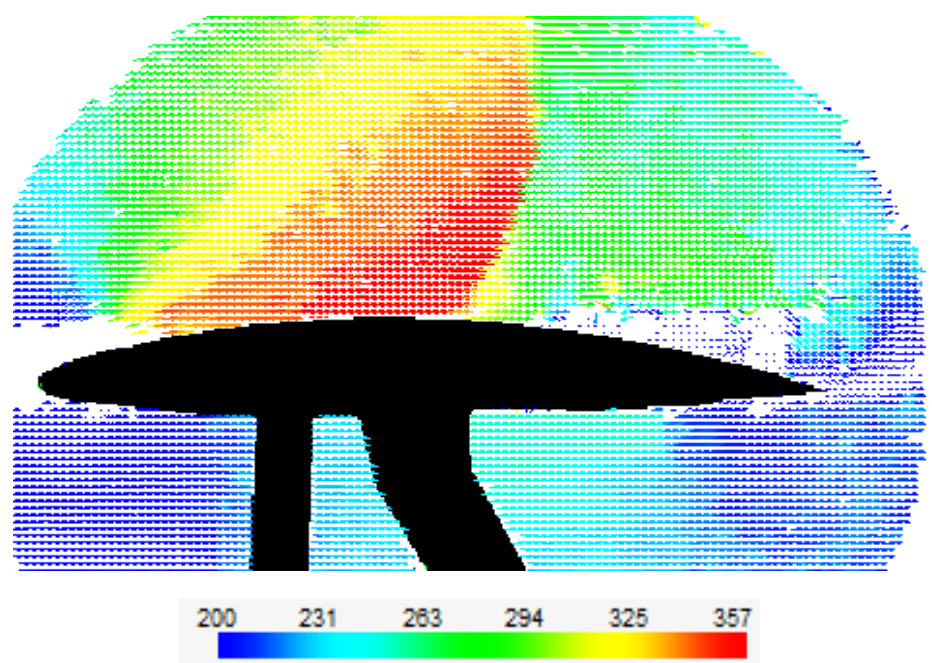

Fig. 6. Exemplary 2D vector velocity field above an airfoil for angle of incidence $4^{\circ}$ and Mach number 0.7. Colors of the velocity map indicated the flow velocity in [m/s] [Stryczniewicz, 2014]

In order to determine the shock wave position the velocity gradient in the freestream direction was calculated. The position of the shock was assigned to the $\mathrm{x}$-coordinate of the maximum value of the velocity gradient. The average location was determined form 300 instantaneous velocity field measurements. The variation of the shock position versus the angle of attack is shown in figure 7 left. The data are presented in dimensionless units referred to the airfoil's chord length $\mathrm{c}$. The location of the shock at $\mathrm{x} / \mathrm{c} \approx 60 \%$ is typical for investigated airfoil. It can be noticed that when the angle of attack was increased the average position of the shock moved closer to the leading edge. The data were used for determination of relation between the angle of attack and the shock motion amplitude. For every angle of attack the difference $\Delta \mathrm{x}$ between maximum $\left(\mathrm{x}_{\max }\right)$ and minimum $\left(\mathrm{x}_{\min }\right)$ distance of shock form the leading edge was determined. Figure 7 presents the variation of $\Delta x$ versus the angle of incidence.

One can notice the range of the shock position variation $\Delta \mathrm{x}$ changed from $13 \%$ to $20 \%$. The transition in the level of shock wave oscillation amplitude occurred for angle of incidence between $3^{\circ}$ and $5^{\circ}$. A small decrease of the period of the shock motion amplitude can be also observed for angle of incidence above $6^{\circ}$. The results correspond well with results of pressure measurements and Schlieren visualization performed in IoA in a course of shock boundary layer investigations on V2C profile in the TFAST project. An increase of shock wave oscillation amplitude over supercritical airfoils for constant Mach number and varying angle of attack is widely reported literature $[4,23,24]$ and related to buffet onset.

The previous section has shown that PIV data analysis can be used for buffet onset investigations. Although sampling frequency of the PIV system did not allow to measure the frequency of the oscillations it was possible to detect an increase of amplitude of periodic shock motions. 

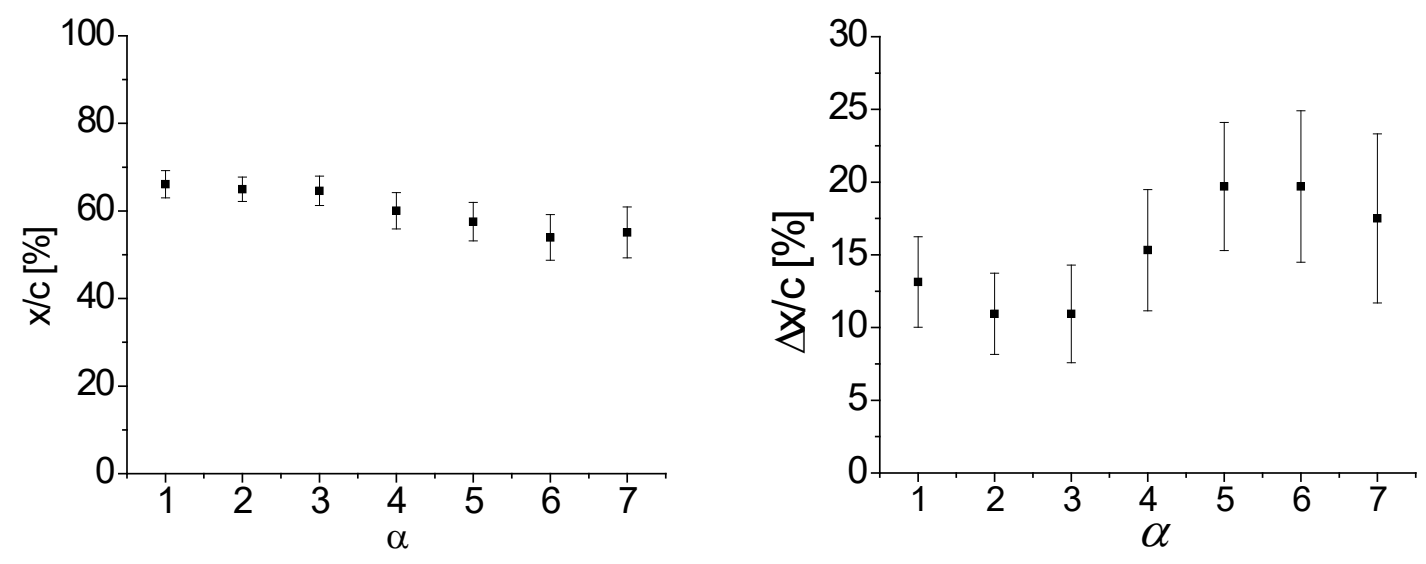

Fig. 7. Position of the shock above the airfoil for various angle of incidence (left). The range of shock oscillations versus the angle of incidence for Mach number 0.75 (right) [Stryczniewicz, 2014]

\section{CONCLUSIONS}

In the article application of two techniques for quantitative compressible flow visualization has been described: Background Oriented Schlieren and Particle Image Velocimetry. Both techniques are based on digital image processing of discrete patterns. The results showed that advances in digital image processing allowed to introduce a new quality to Schlieren experimental testing. In the second part, an application of Particle Image Velocimetry for unsteady transonic flow investigation has been described. As it was presented, the state of the art flow visualization techniques allow to measure the density and velocity fields at high speeds in 2D flows.

It is worth mentioning that the current state of art quantitative volumetric measurement techniques (especially time resolved tomographic and volumetric PIV and PTV) allowed to develop procedures for extract pressure fields form flow velocity field data. The advances may pave the way for robust non-intrusive pressure and aerodynamic load determination in wind tunnels for aeroelastic and aeroacoustics research. Those new techniques will be especially important for investigations of compressible flows in transonic and supersonic flow regime, for example, for studies on noise reduction of commercial airliners.

\section{BIBLIOGRAPHY}

[1] Anderson J.D., 2004, "Fundamentals of Aerodynamics", 5th edition, McGraw-Hill's

[2] Galinski C. and Goraj Z., 2004, "Experimental and numerical results obtained for a scaled RPV and a full size aircraft", Aircraft Engineering and Aerospace Technology, No. 76, pp. 305-313.

[3] Żółtak J. and Stalewski W., 2014, "Preliminary Design of the Air-Intake System and the Nacelle in the Small Aircraft-Engine Integration Process", Aircraft Engineering and Aerospace Technology, No. 86, pp. 250-258.

[4] Lee B.H.K., 1989, "Investigation of flow separation on a supercritical airfoil", Journal of Aircraft, No. 26, pp. 1032-1039. 
[5] Adrian R.J., 1991, "Particle-imaging techniques for experimental fluid mechanics", Annual Review of Fluid Mechanics, No. 23, pp. 261-304.

[6] Wilert C.E., Gharib M., 1991, "Digital particle image velocimetry", Experiments in Fluids, No. 10, pp. 181-193.

[7] Parsad A.K., 2000, "Stereoscopic particle image velocimetry", Experiments in Fluids, No. 29, pp. 103-116.

[8] Scarano F., 2013, "Tomographic PIV: principles and practice”, Measurement Science and Technology, No. 24, pp. 1-28.

[9] Raffel M., 2015, "Background-oriented schlieren (BOS) techniques", Experiments in Fluids, No. 56, p. 60.

[10] Stryczniewicz W. 2012, “Development of Particle Image Velocimetry Algorithm”, Problems of Mechatronics, No. 9, pp. 41-54.

[11] Venkatakrishnan L., Meier G.E.A., 2004, "Density measurements using the Background Oriented Schlieren technique”, Experiments in Fluids, No. 37, pp. 237-247.

[12] Manovski P., Wehrmeyer J., Scott K., Loxton B., Quick H., Lam S. and Giacobello M., 2016, “A Performance Comparison between Classical Schlieren and Background-Oriented Schlieren", $18^{\text {th }}$ International Symposium on the Application of Laser and Imaging Techniques to Fluid Mechanics, Lisbon, June 04-07.

[13] Clem M.M., Zamam K.B.M.Q. and Fagan A. F., 2012, "Background Oriented Schlieren Applied to Study Shock Spacing in a Screeching Circular Jet", 50 th AIAA Aerospace Sciences Meeting Including the New Horizons Forum and Aerospace Exposition, Nashville, January 09-12.

[14] Heineek J. T., Banks D. W., Schairer E. T., Haering E. A. and Bean P. S., 2016, "Background Oriented Schlieren (BOS) of a Supersonic Aircraft in Flight”, AIAA Flight Testing Conference, Washington D.C., June 13-17.

[15] Bauknecht A., Merz C.B. and Raffel M., 2014, "Airborne Application of the Background Oriented Schlieren Technique to a Helicopter in Forward Flight", $17^{\text {th }}$ International Symposium on the Application of Laser and Imaging Techniques to Fluid Mechanics, Lisbon, June 07-10.

[16] Raffel M., Willert C.E., Wereley S.T. and Kompenhans J., 2007, "Particle Image Velocimetry, a practical guide". 2nd edition, Springer-Verlag.

[17] Surmacz K., Ruchała P and Stryczniewicz W., 2016, "Wind tunel tests of the developement and demise of Vortex Ring State of the rotor". In Kleiber Advances in Mechanics: Theoretical, Computational and Interdisciplinary Issues, CRC Press.

[18] Urban J.M., Zloczewska A, Stryczniewicz W, and Jönsson-Niedziolka M., 2013, "Enzymatic oxygen reduction under quiescent conditions - The importance of convection", Electrochemistry Communications, No. 34, pp. 94-97.

[19] Jun Z., Zhenghong G., Hao Z. and Junqiang B., 2009, "A high-speed nature laminar flow airfoil and its experimental study in wind tunnel with nonintrusive measurement technique", Chinese Journal of Aeronautics, No. 22, pp. 225-229.

[20] Raffel M. and Kompenhaus J., 1993, "PIV measurements of unsteady transonic flow fields above a NACA 0012 airfoil”, Laser Anemometry Advances and Applications, No. 2052, pp. 527-534.

[21] Giepman R.H.M., Schrijer F.F.J. and van Oudheusden B. W., 2015, "High-resolution PIV measurements of a transitional shock", Experiments in Fluids, No. 56, pp. 113-133.

[22] Hartmann A., Klaas M. and Schröder W., 2010, "Time resolved stereo PIV measurements of unsteady shock-boundary layer interaction on a supercritical airfoil", 15th Int Symposium on Applications of Laser Techniques to Fluid Mechanics, Lisbon, July 5-8. 
[23] Wiśniowski W., 2014, "Specializations of the Institute of Aviation - review and conclusions", Transactions of the Institute of Aviation, No. 235, pp 7-16.

[24] Stryczniewicz W. and Surmacz K., 2014, "PIV Measurements of the Vortex Ring State of the Main Rotor of a Helicopter", Transactions of the Institute of Aviation, No. 235, pp. 17-27.

[25] McDevitt J.B., Levy L.L. Jr. and Deiwert G. S., 1976, "Transonic Flow About a Thick Circular-Arc Airfoil", AIAA Journal, No. 14, pp. 606-613.

[26] Mundell A.R.G. and Mabey D.G., 1986, "Pressure fluctuations caused by transonic shock/ boundary-layer interaction”, Aeronautical Journal, No. 90, pp. 274-282.

\section{JAKOŚCIOWE WIZUALIZACJE PRZEPŁYWÓW ŚCIŚLIWYCH}

\section{Streszczenie}

Artykuł przedstawia możliwości zastosowania jakościowych metod wizualizacji przepływu do badań przepływów ściśliwych. Przedstawiono dwie metody umożliwiające pomiar parametrów pola przepływającego płynu: anemometrię obrazową oraz technikę fotografii smugowej opartej na obrazowaniu tła. Ostatnio opracowana nowa metodyka pozwala na rozwinięcie klasycznej techniki Schlierena, dzięki wykorzystaniu cyfrowej analizy obrazu umożliwia jakościowy pomiar gradientów gęstości. W publikacji przedstawiono przegląd zastosowań techniki fotografii smugowej wykorzystującego obrazowanie tła do jakościowego pomiaru zmian gęstości przepływów ściśliwych. Anemometrii obrazowa jest techniką wizualizacyjną, umożliwiającą bezinwazyjny pomiar pola prędkości przepływającego płynu. W publikacji przedstawiono zastosowanie anemometrii obrazowej do wyznaczenia pozycji fali uderzeniowej ponad powierzchnią profilu dla okołodzwiękowych prędkości przepływu. Przedstawione wyniki wykazały, iż zastosowanie technik jakościowej wizualizacji przepływu umożliwia pogłębienie analizy badanych zjawisk w warunkach przepływu okołodźwiękowego i naddźwiękowego, takich jak oddziaływanie fali uderzeniowej z warstwą przyścienną oraz oderwania przepływu spowodowanego falą uderzeniową.

Słowa kluczowe: przepływ ściśliwy, wizualizacja przepływu, badania tunelowe, anemometria obrazowa, fotografia smugowa. 